\title{
Autobiographical turning points: Remembering and forgetting
}

\begin{tabular}{|c|c|}
\hline \multicolumn{2}{|c|}{$\begin{array}{l}\text { Author: } \\
\text { Michael Sheringham }{ }^{1}\end{array}$} \\
\hline \multicolumn{2}{|c|}{$\begin{array}{l}\text { Affiliation: } \\
{ }^{1} \text { All Souls College, Oxford } \\
\text { University, United Kingdom }\end{array}$} \\
\hline \multicolumn{2}{|c|}{$\begin{array}{l}\text { Correspondence to: } \\
\text { Nicholas Meihuizen }\end{array}$} \\
\hline \multicolumn{2}{|c|}{$\begin{array}{l}\text { Email: } \\
\text { 23459220@nwu.ac.za }\end{array}$} \\
\hline \multicolumn{2}{|c|}{$\begin{array}{l}\text { Postal address: } \\
\text { PO Box 20677, Noordbrug } \\
\text { 2522, South Africa }\end{array}$} \\
\hline \multicolumn{2}{|c|}{$\begin{array}{l}\text { Dates: } \\
\text { Received: } 23 \text { July } 2015 \\
\text { Accepted: } 27 \text { July } 2015 \\
\text { Published: } 18 \text { Sept. } 2015\end{array}$} \\
\hline \multicolumn{2}{|c|}{$\begin{array}{l}\text { How to cite this article: } \\
\text { Sheringham, M., 2015, } \\
\text { 'Autobiographical turning } \\
\text { points: Remembering and } \\
\text { forgetting', Literator } 36(2) \text {, } \\
\text { Art. \#1229, } 8 \text { pages. http:// } \\
\text { dx.doi.org/10.4102/lit. } \\
\text { v36i2.1229 }\end{array}$} \\
\hline \multicolumn{2}{|c|}{$\begin{array}{l}\text { Note: } \\
\text { This was the keynote address } \\
\text { of the Autobiography } \\
\text { Workshop at North-West } \\
\text { University, Potchefstroom } \\
\text { Campus, in August } \\
\text { 2014. It is included here } \\
\text { by kind permission of } \\
\text { Michael Sheringham, on } \\
\text { the understanding that } \\
\text { its special character as } \\
\text { an oral presentation be } \\
\text { adhered to. For this reason, } \\
\text { references and other } \\
\text { scholarly appurtenances and } \\
\text { conventions have been kept } \\
\text { to a minimum. }\end{array}$} \\
\hline \multicolumn{2}{|c|}{$\begin{array}{l}\text { Copyright: } \\
\text { (C) 2015. The Authors. } \\
\text { Licensee: AOSIS } \\
\text { OpenJournals. This work is } \\
\text { licensed under the Creative } \\
\text { Commons Attribution } \\
\text { License. }\end{array}$} \\
\hline \multirow{2}{*}{ 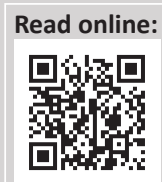 } & \\
\hline & $\begin{array}{l}\text { Scan this QR } \\
\text { code with your } \\
\text { smart phone or } \\
\text { mobile device } \\
\text { to read online. }\end{array}$ \\
\hline
\end{tabular}

The autobiographical process involves not just reporting on past events, reconstructing one's life history, but replaying events in different voices and modes. It may be that the autobiographer is motivated by the desire to impose one version of her or his life and to scotch the others. Even then, however, other versions, the ones under erasure, often show through the fabric - the fabrication - and we detect their traces in the turns of the rhetoric. Thus, in autobiography, the real agenda is often underneath, either because a less official motive lurks behind the manifest ones or because what really drives the project of selfscrutiny is something only progressively revealed in the process of writing. This issue takes into consideration the structuring implications of turning points in the account of a life and the roles of the converse forces of forgetting and subjective destabilisation. There are two ways of looking at turning points: either as causative agents of order and coherence or as metaphors as provisional, semi-fictional, forensic, cognitive instruments. In the latter case, they belong to an active, performative, conjectural, self-revising process, and they complement a version of autobiographical memory that involves a constant interplay of remembering and forgetting.

Outobiografiese keerpunte: Onthou en vergeet. Die outobiografiese proses behels nie net die optekening van gebeurtenisse uit die verlede en die rekonstruksie van 'n mens se lewensverhaal nie, maar ook die herhaling van gebeure in verskillende stemme en modusse. Die outobiograaf mag gedryf wees deur die begeerte om 'n enkele weergawe van sy of haar lewe voorop te stel, met die gevolg dat ander weergawes onderdruk word. Selfs dan skyn ander weergawes, dié wat geskrap is, dikwels deur die weefsel - deur die fabrikasie - en merk ons hulle spore in wendings van die retoriek. Gevolglik is die ware agenda in 'n outobiografie dikwels weggesteek, hetsy omdat 'n minder amptelike motief agter die manifeste motiewe skuil of omdat dit wat werklik die projek van selfondersoek aandryf, iets is wat slegs in die loop van die skryfproses onthul word. Hierdie saak neem die strukturerende gevolge van keerpunte in die relaas van 'n lewe in ag, en ook die rol wat die botsende kragte van vergeet en subjektiewe destabilisasie daarin speel. Keerpunte kan op twee maniere beskou word: as agente wat orde en koherensie veroorsaak, of as metafore - dit wil sê, as voorlopige, semi-fiksionele, forensiese, kognitiewe instrumente. In laasgenoemde geval maak hulle deel uit van 'n aktiewe, performatiewe, bespiegelende, selfhersieningsproses, en komplementeer hulle 'n weergawe van die outobiografiese geheue wat uit ' $n$ konstante wisselwerking tussen onthou en vergeet bestaan.

\section{Introduction}

\section{Background}

Autobiography is clearly an art of memory, and autobiographers, starting with Saint Augustine, who devoted a whole section of his Confessions to this topic, often talk about the operations of memory. However, the questions I want to ask have more to do with the designs that autobiographers may have on their memories - the kinds of pattern or design they may make out of them. It also has to do with the designs that autobiographers may come to feel that their memories have on them as they engage with material that preys on, disorientates, destabilises them - and perhaps induces them to forget rather than to remember.

As a way in to my concerns, I want to talk about a poem that can help set the scene of autobiography, a transaction we can have with ourselves, and with others, a game we can play with words, earnestly or frivolously, for high or low stakes, as we wish.

The untitled poem - 'La servante au grand cœur dont vous étiez jalouse' - is from Baudelaire's Les Fleurs du Mal. Here it is in Roy Campbell's (1952) translation:

Now the great-hearted servant, who aroused

Your jealousy, in humble earth is housed, 
Let's take, at least, some flowers for her relief

The dead, the piteous dead, know piercing grief, And when October blows, to prune old trees, And whistles round the marble where they freeze, How thankless then we living must appear Between warm sheets to sleep in comfort here, While, eaten by black dreams, they lie in woe Warm bedmates and their gossip to forego, Frostbitten skeletons, tunnelled by vermin, To bear the moulting drip of Winter's ermine, For ages, with no friends nor kindred there The tatters on their railings to repair.

On evenings when the hearthlogs hiss and flare Were I to see her calmly take her chair: Or, in the calm and blue December gloom, Huddle within the corner of my room, Gravely returning from her bed eternal To tend this grown-up child with the maternal Care of old times - how could I then reply

To see the tears roll from each hollow eye? (p. 237)

The first of the poem's two parts is fairly general: The servant is quickly assimilated to a general category, the dead, and we lose sight of her as we are swept up in an evocation of how the dead must feel. The second is much more intimate. We move from outside - cold, windy cemeteries - to inside: the poet's room at night. We then move back towards the poet himself, who now imagines a kind of visitation by the old servant, long dead and buried.

In the first part, by a winding route and several gear changes, the poem progressively pitches everything up to a high level of intensity. From the 'tandis que' [While] in line 9, when we switch back to the dead, the winding syntax, the accumulation of clauses and epithets and the gothic touches worms, snowy wastes, the compelling imagery of vast drifts of time experienced drop by drop - all take us on an emotional journey belied by the apparently impersonal statements.

In the second part, we are led back over the same ground though it now bears a very different aspect. It entails a new cadence, rising upwards and then down; a complex word-order matching the disorientation that the poem will register; a change of month, October becoming December; and a change of locale, to a different lieu de mémoire, inside rather than outside. However, it has the same protagonists: the mother (still the implicit addressee, though not referred to, even indirectly); the servant - but initially there only as a pronoun, 'her'; and the speaker, designated by the pronoun ' $\mathrm{je}^{\prime}$ ('I') for the first time, no longer hiding behind a protective 'we'. It also has the same strategy of conjecture: 'What if' and 'as if' now become an interrogative: 'how could I then reply?'

What if, rather than we visiting her, she visited me in the cold clarity of a December night? Obsessionally, the poem plays this fantasy through three times. Firstly, it does so in a homely way - she would calmly sit down by the fireside. Secondly, it does so in a scenario where the old servant is a rather unheimlich visitant whom one would find squatting - 'huddled' - in a corner. In a third version, neither skittish nor ghoulish - and this is where we get to the point - she is imagined to come as a revenant from the past: 'Grave, et venant $\mathrm{du}$ fond/de son lit éternel' [Gravely returning from her bed eternal]. The tempo accelerates, the vocabulary is heightened, the assonance and coagulation of sounds are more marked. The thought is that she would have come back to cast her motherly eye over the child now grown up but made child-like again in this fantasy. (The word 'maternel' suggests that the mother was right to be jealous, and the poem may revive her jealousy, a risk that autobiography often courts by being performative.)

The poem ends by a return to simple diction, by the resolution of the 'Were I' clause into a rhetorical question: If she came back in one, or all three, of these ways, how could I respond in the face of her distress, how could I reply to the tears of this pious soul?

Why is it central to the way the poet imagines this encounter that the old servant should be crying? No doubt because what is staged here is not really the look of another - her eye sockets are hollow, her tears therefore incongruous - but a look at, a confrontation with, oneself. To imagine - to stage the perspective of another, of someone who was witness to our formative years, engenders self-awareness. What could the poet reply given that the tears he places in her eyes might be tears of reproach? Imagining, staging, her look is a way of looking at himself and recognising that, in the face of her goodness and piety, all the excuses he might offer - oversubtle self-justification, appeal to circumstance, adversity, misfortune - would be beside the point.

In the compass of 22 lines - but by a long detour, going via tender homage, imaginings about the dead, which rapidly rehearse a whole range of tropes and scenarios, ancient and modern, and by public and private reference - the poem talks about witnessing and being witnessed, remembering and being remembered, covering much more ground than first appears. Gradually the poem reveals what thinking about the old servant Mariette is really about. It is about the speaker being forced to look at himself through her eyes and to ask what he has made of his life. Here is a look which makes no claim on him: He cannot impugn her motives, suggest for instance that she look to herself, and so he must either endure or divert her sightless gaze, turning it into another exchange of looks - between the poet and himself. If this selfconfrontation is the central drama, the poem builds up to it slowly. It is as if the poet knew from the start that to remember 'la servante' is to confront himself, but he then tried to ward off this realisation by feeling sorry for her, making a mental note to flower her grave, fantasizing about the poor old dead, and so on. It is as if all of this were a screen designed to divert attention from the truth but a screen progressively woven out of, and then unravelled by, the very feelings it is designed to protect the poet from.

How does 'La servante au grand coeur' provide insights into what I shall call the scene of autobiography? First of all, it 
points to the theatricality of autobiography itself, where the text becomes a stage for a transaction with oneself, where different versions, different possible selves - including how we imagine others see us - are in play. Chateaubriand and Stendhal both talk about the 'quantity of Is' with which they found themselves dealing in their autobiographies, and Stendhal refers to adopting different 'positions d'âme' [positions of the soul] - 'subject positions' in modern theory parlance - as he stirs his memory into action and analyses its findings. The autobiographical process involves not just reporting on past events, reconstructing one's life history, but replaying events in different voices and modes. It may be that, quite often, the autobiographer is motivated by the desire to impose one version - perhaps, as in Rousseau's case, the version that will give the lie to what one thinks other people are saying - and to scotch the others. Even then, however, other versions, the ones under erasure, often show through the fabric - the fabrication - and we detect their traces in the turns of the rhetoric. In autobiography, as in Baudelaire's poem, the real agenda is often underneath, either because a less official motive lurks behind the manifest ones or because what really drives the project of self-scrutiny is something only progressively revealed in the process of writing.

What is at issue here, in part, as in 'la servante au grand coeur', are different degrees of identification with others, but also with aspects of oneself, and different degrees of self-distance and proximity. Baudelaire's poem also points to the fact that autobiography is a discourse addressed to someone - real or imaginary - where the relationship to an implied reader and how that relates to real readers is part of the intersubjective space, the stage, of the autobiographical transaction. 'La Servante au grand coeur' also indicates the role that language itself plays in autobiography where tones of voice, the colouring of words and phrases and the twists and turns of discourse, often freighted with other voices - those of earlier practitioners (autobiography is highly intertextual and citational) and those characteristic of certain types of discourse: confession, vindication, excuses - may be crucial.

Now, all these features of autobiography bear on memory, which in autobiography is not so much a faculty as a terrain, the location for a body of material to be worked with, as voices are woven together on a stage. As Walter Benjamin (2006:27) wrote in his Berlin childhood: 'Memory is not an instrument for exploring the past but its theatre.' 'The oldhearted servant' is a pre-autobiographical poem in that it takes us to the brink of autobiography with the question: 'que pourrais-je répondre?' [how could I then reply?]. What is the next step?

Very often, of course, it is to tell the story of one's life, to turn it into a narrative. Baudelaire (2013) himself was tempted in this direction and began taking notes towards a possible autobiography with a projected title inspired by Poe, My heart laid bare (Mon Coeur mis à nu). However, the fragments he assembled, whilst they were to constitute one of the poet's most fascinating posthumous works, were to remain as fragments. What if it had been otherwise?
Like many autobiographers, Baudelaire, in reconstituting his life-story - in trying out some replies to his old nurse might well have been tempted to identify a turning point or two in his life (in the event, Jean-Paul Sartre was to do this for him, basing a remarkable book-length biography of the poet on the turning point of his mother's remarriage). Ever since Saint Augustine, the identification of turning points has been central to autobiography as a narrative project. Their attraction is obvious: 'There I was, going nowhere in particular, being anyone in particular and suddenly, bingo, I read Homer, saw Venice, met my wife, or found God'. The permutations are endless, the structure much the same: before and after, then and since.

If turning points are part of the lingua franca of autobiography, how does their prevalence square with the picture of autobiography I drew on the basis of 'La Servante au grand coeur' - autobiography as process, transaction, theatre - and also as a space where remembering vies with forgetting?

Let us start with the big question, the turning point of turning points.

Augustine's great turning point is the 'Tolle, lege' incident. The year is 386 CE. Augustine is a Professor of Rhetoric, residing in Milan. He is in a dreadful state: One by one, all of his intellectual doubts, emotional reservations and scruples about Christianity have been dispelled. No longer a Manichean, he is available and in principle willing. $\mathrm{He}$ is, however, stuck on the brink, unable to cross the divide between his old self and a new one, seemingly incapable of giving up his old attachments. He goes out into the garden in tears and throws himself down by a fig tree. And then it happens. He hears 'the sing-song voice of a child in a nearby house' saying, again and again, the words 'Tolle, lege, tolle, lege' [Take it and read it, Take and read]. He wonders if it is a children's game, concludes that it is not and assumes that this must be a 'divine command' to 'open my book of scripture and read the first words on which my eyes should fall'. He picks up the copy of Paul's Epistles that he had jettisoned earlier and reads the first passage on which his eyes alight. It is an exhortation to give up bodily appetites in favour of Christ, and it fits him like a glove, or a glass slipper: He tells us that by the time he had reached the end of the sentence, all his doubts had been dispelled and confidence filled his heart (Augustine 1961:VIII, 12).

This was a turning point.

Or was it? Certainly it makes a good story. When we read Confessions, this sequence pulls Augustine's life into focus. It gives what was inchoate a clear shape. How appropriate is it, however, to suggest that this moment gave Augustine's life its meaning, turned it into a destiny? In many ways, it is obvious that the 'Tolle, lege' is symbolic rather than real. Far from coming out of the blue, the incident is the culmination of a complex process recounted in detail, and the moment of conversion is foreshadowed in numerous ways. For example, just prior to this in the narrative, a friend, Ponticianus, tells 
Augustine about Anthony of Egypt's conversion, which had involved falling on some words from St Matthew, and then another story about a colleague whose conversion had been prompted by reading a life of Anthony. Augustine's description of this act of reading is remarkable for its account of a spirit in the throes of metamorphosis:

... he turned back to the book, labouring under the pain of the new life that was taking birth in him. He read on, and in his heart, where you $[\mathrm{God}]$ alone could see, a change was taking place. (Augustine 1961:VIII, 6)

Augustine acknowledges the impact on him of his friend's account of the effects, on one man, of reading about the conversion of another:

While he was speaking, O Lord, you were turning me around to look at myself. For I had placed myself behind my own back, refusing to see myself. You were setting me before my own eyes ... (Augustine 1961:VIII, 7)

If the multiple strands and mirrorings of Augustine's narrative undermine the literal truth of a chain of events, what is conveyed is an inner process working at several levels, turning on the difficulty of breaking the chain of habit and the feeling of being 'one soul torn between conflicting wills' (Augustine 1961:VIII, 11). We are shown someone who knows obscurely that he is changing, but is somehow frozen, unable to break out of his old self.

This suggests that there are two main ways in which we could look at autobiographical turning points. We could see them as metaphors, manners of speaking about complex processes that they serve to reveal, just as in Augustine the turning point can be seen as a catalyst, a knock from the external world. Seen this way, the turning point is an instrument like a medieval speculum. Alternatively, we can see the turning point as a causative agent, an event that takes things in new directions.

Now, the second view has been surprisingly prevalent in discussions of autobiography, not for the good reason that it confirms our sense that things out of the blue do change people's lives but for the possibly bad reason that, because autobiographers often go on about turning points, they must be compulsory elements in this genre. Critics of autobiography have often been obsessed with the idea that what autobiographers really want is unity, shape, coherence and meaning. This gives a kind of Identikit picture of the autobiographical life as hanging on a moment, or moments, of conversion or revelation with only details in between The Augustinian legacy is still partly responsible for this. The 'tolle, lege' scene echoes down through Petrarch, Saint Teresa, Georges Sand, Edmund Gosse and countless others: Conversion narratives abound. Moreover, the 'tolle, lege' scene feeds numerous visual representations, including a famous painting by Fra Angelico where the ambiguity of the incident is filtered out. After all, the way Augustine tells it, he had to decipher the child's words, open the book and decide what the words meant; there are crucial moments of interpretation and decision. For their part, paintings of the 'tolle lege' scene often depict chubby angels bearing scrolls and little flags emblazoned with the magic words 'tolle lege' as in a game show where the grinning compere says: 'Go on, open the box.'

The consequence of all this is that talk of turning points in the context of autobiography tends to maintain the idea of a quest for secure meaning, stable identity, unity and coherence. Not so long ago, partly in the context of writing his own autobiography, the critic Frank Kermode decreed that, despite everything, autobiography remained Augustinian rather than Freudian. (I shall come back to Freud later.) Autobiographical memory was, he argued, always an instrument of personal continuity (Kermode 2010). However, this tends, I think, to downplay many of the constituents of the scene of autobiography and to associate it too closely with the appeal to the consolations of order - any order - in the face of the mess of experience.

Of course, I do not deny the importance of recognising this component in autobiography, of acknowledging the way in which autobiographers give expression to a more general desire that our life-stories should be meaningful and coherent. Turning points answer a need. They can provide lives with the kinds of shape we associate with fiction, allegory and drama. This fact deserves recognition but also, as I have suggested, scepticism. For an amusing, but also thoughtprovoking, instance of this scepticism, let us turn to no less an authority than the master, Henry James. William Dean Howells once put it to his friend James that 'every man's life had had its turning-point', and he went on to suggest:

that there were cases, particular lives, as to which some account of what had turned on it, and how and why the turn had come, couldn't fail to be interesting. (James 1987:438)

'I glanced back at my own career in the light of this generalisation', James (1987:438) tells us, but he could not at first see how it might apply in his own case. Howells persisted: surely James's year at the Harvard Law School where he spurned legal studies and began writing creatively, 'must have' constituted a turning point? 'Let me say at once', James (1987) observes:

... that I welcomed the suggestion - for the kindly grace of it, the element of antique charm and bedimmed romance that it placed, straight away, at the disposal of my memory; by which I mean that I wondered whether I mightn't find, on ingenious reflection, that my youth in fact enjoyed that amount of drama. I couldn't, I felt, be sure ... (p. 438)

James's scepticism could scarcely be more patent: 'ingenious reflection' sounds like a euphemism for arbitrary fabrication, 'romance' and 'drama' seem to place the turning point squarely in the domain of fiction. James, we may surmise, is politely holding his friend's idea at arm's length, savouring it in purely aesthetic terms. Consider, though, the novelist's fine evocation of the 'momentous junctures in question':

Occasions of the taking of the ply that is never again to be lost, occasions of the true vocation or the right opportunity recognised 
more or less in a flash, determinations in short of character and purpose and above all of a sharper and finer consciousness. (James 1987:438)

The element of melodrama is undeniable but so is the powerful appeal of the idea. James's fragment highlights the ambiguity of turning points. Whilst his friend thinks that they have an objective or official status, James sees them as the products of ratiocination and semi-fictive construction. To look for a turning point is to examine one's life in a certain way, responding to the appeal of 'the question itself'. For James, the turning point, we could say, is a cognitive device that fosters a certain kind of attention to the self. It marks a particular kind of transaction between the individual and his or her past experience.

I now want to refocus this discussion of turning points by linking it back to the scene of autobiography as a stage on which one deals with memory's ways of returning, or withholding. I also want to associate the two basic ways of regarding turning points that I have identified so far with two ways of thinking about autobiographical memory and particularly with two ways of understanding how autobiographical remembrance relates to forgetting. The central point underlining these remarks is the desirability, as I see it, of acknowledging the crucial importance of forgetting in the autobiographical process. However, as we shall see, if there are different kinds of turning point, and different kinds of remembering, so there are different kinds of forgetting.

Firstly, I want to link the idea that turning points provide form, unity, shape and coherence to the view that autobiographical memory consists quintessentially in the restoration of continuity through anamnesis (the word Plato used for the recollection of eternal forms). This is an obvious link because the whole notion of autobiography as a revelation of order tends to be supported by a celebration of memory's bounty, the capacity of the past to come flooding back in a rich organic flow. However, I want to point to a less familiar connection by suggesting that this kind of memory constitutes a way of forgetting. In the kind of remembrance which homes in on turning points and uses them to understand a life's shape, Mnemosyne - the mother of the Muses - leads towards Lethe, the river of oblivion, where the souls drink to forget in preparation for an unencumbered after-life. The reason for this is simple. In staking out a life, turning points can put forward an official version, allocating memories their meanings, in a fixed scheme of things, and in so doing annihilating the openness they had, the virtuality or pregnancy of meaning with which memories are endowed until we decide once and for all what they mean. If we see remembering something fully as bringing it into the clear light of day and fitting it up with a meaning, then we should accept as a corollary that such remembrance works by engendering oblivion. No more will that memory have any other meaning than the one allocated: Like a butterfly captured, transfixed, categorised and exhibited, it will say one thing and one thing only. That is one of the ways in which autobiographical memory is therapeutic: It sorts, selects and assembles, and in so doing, evacuates, exorcises, liquidates. It installs clarity where there was darkness.

In this light, Frank Kermode's distinction between the Augustinian and the Freudian collapses. Kermode acknowledges that Freudian memory is about forgetting, or as the psychoanalyst Adam Phillips (1994:28) puts it, the analytic process allows '... the past to be released through [memory] into oblivion', but Kermode (2010) denies that this is Augustine's, or autobiography's, way.

And yet, I think that it very often is autobiography's way. Phillips's essay, 'Freud and the uses of forgetting', begins with the sentence: 'People come for psychoanalytic treatment because they are remembering in a way that does not free them to forget' (Phillips 1994:22), and in 'The telling of selves', he observes that '... we use the continuity of our lifestories to conceal our past' (Phillips 1994:67). A life staked out with clear turning points may be a life remembered, but it may also, in a profounder sense, be a life forgotten, buried, covered over, although not definitively. The organised life of autobiography can resemble a kind of mausoleum where an embalmed effigy lies in state. Milan Kundera, in The book of laughter and forgetting, plays variations on the idea that official memory acts by suppressing, erasing, or purging and that true memory is a struggle against such forgetting (Kundera 1999:218).

Virginia Woolf's 'A sketch of the past' provides an example. Woolf notes that she had been obsessed by her mother, who died when she was thirteen, until a day when she was walking around Tavistock Square and suddenly 'made up', as she puts it, To the lighthouse:

I wrote the book very quickly, and when it was written, I ceased to be obsessed by my mother ... I suppose that I did for myself what psychoanalysts do for their patients. I expressed some very long felt and deeply felt emotion. And in expressing it I explained it and then laid it to rest. But what is the meaning of 'explained' it? (Woolf 1953:81)

The question is very pertinent because the whole essence of 'A sketch of the past' is that Woolf reopens the question of her mother and develops a different kind of explaining, a different kind of remembering, which does not consist in creating aesthetic order but in sifting, reconstructing, identifying the borders of the public and the private, the remembered and the forgotten, fact and fiction.

That leads me to the second way of thinking about the links between turning points, memory and forgetting. Here, turning points are not instruments of definitive order. They are, rather, provisional, semi-fictional, forensic, cognitive instruments as suggested half-jokingly by Henry James. They belong to an active, performative, conjectural, self-revising process, and they complement a version of autobiographical memory that involves a constant interplay of remembering and forgetting. Instead of pulling a past into order, the 
autobiographer's life is conceived as an ongoing narrative, actively transformed by the present process of recollection.

Nowhere is this brought home more vividly than in the Autobiography of Malcolm X (1987), a book which could appropriately be subtitled: A tale of two turning points. When Malcolm X agreed to tell his story to Alex Haley, the Augustinian plot-line was clear. The narrative would turn on the moment in a Southern penitentiary that led to the transformation of Malcolm Little - hustler, hoodlum, pimp into Brother Malcolm X, devout follower of Elijah Mohammed, pillar of the black Muslim movement, and ultimately its most prominent apologist. What makes the autobiography so gripping is that, in the very period when it is being composed, mainly in impromptu all-night monologues to Alex Haley, fitted into the gaps in Malcolm's punishing schedule as spokesman for the black Muslims, another change is taking place. Progressively Malcolm X (Malcolm X 1987:xxix-xxx) is coming to see that the black Muslim creed is a sinister form of inverted racism and above all a travesty of the authentic faith of Islam. So Malcolm's second turning point (but as in Augustine's case, we are in fact dealing with a cumulative process of inner transformation) takes place when he visits the Middle East, goes to Mecca and then returns to America with a newly-grown beard and a new name: El-Hajj Malik El-Shabazz. From this point on, however, he knows that he is a marked man. He knows the black Muslims will not tolerate his defection, and he is duly gunned down when he goes to make a speech at a Harlem ballroom.

I am attempting to delineate a view of autobiographical process where remembering is never definitive and where forgetting is not just suppression. It is a process where the aim is not so much to represent the past as to interrogate it. If representation can often be said to kill memory, it is because it produces memories that are screens (turning points, in their plenitude, often have the air of screen memories in the Freudian sense). In seeking to show, representation secretes, engendering pockets of forgetfulness. In contrast, the autobiographical process I am describing sees the forgotten as its target but does not presume to eradicate it as such. The kind of autobiographical memory I am referring to not only acknowledges the forgotten but acknowledges that the work of memory is also the work of forgetting, that the two are inseparable. To remember one way is to forget in another. Forgetting is an active ingredient in the memory process, and autobiography deals not just with the forgotten but also with forgetting.

A late play by Samuel Beckett, That time (Beckett 1986:387395), highly autobiographical in content and form, illuminates some aspects of this theatre of memory via a brilliant stage image. We see on stage an old man who does not speak but who hears his own recorded voice at three moments in the past. The three narratives are intercut, spliced together, so that we go back and forth between the three, piecemeal. Yet if we focus on them individually, each is concerned with a 'that time' which might have been a turning point. Furthermore, each potential turning point relates not so much to an outer event as to an inner reordering of memory, a shift in the balance between the remembered and the forgotten. In each case, the routine of memory is broken.

The second narrative concerns memories of a key scene from the man's youth when a woman said she loved him, and he just sat 'stock still' beside her on a rock. We are given to understand how he has habitually dealt with this memory, the inner patter he uses to keep it official, to keep it at bay, out there on the screen of representation, 'making it up that way to keep it out on the stone' (Beckett 1986:394). Then we gather that, on the 'that time' in question, this strategy failed him, there were 'no more words to keep it out' (Beckett 1986:394), the memory had caught him unawares while he was at a window and heard an owl:

... that time in the end when you tried and couldn't by the window in the dark and the owl flown to hoot at someone else ... no words left to keep it out so gave up there by the window in the dark or moonlight gave up for good and let it in and nothing the worse the great shroud billowing in all over you on top of you and little or nothing the worse little or nothing. (Beckett 1986:394)

The third narrative strand deals generically with turning points, with moments of which one feels (or decrees) in retrospect that, one was '... never the same after that' (Beckett 1986:390). However, the types of events recalled, all involve being in a public building - a portrait gallery, a public library, a post office - and experiencing the dissolution of identity. In the first instance, the memory is of a moment when '... you started not knowing who you were from Adam' (Beckett 1986:390). But the turning point enshrined in the narrative present - the present realisation - is that turning points themselves are bogus, that their connotations of before and after, up till then and ever since, do not really fit with a profound sense of continuity, or discontinuity, an apprehension of experience where time is much more fluid, where there are no events (at least since the primordial one of birth) but only changes:

... never the same but the same as what for God's sake did you
ever say I to yourself in your life come on now could you ever
say I to yourself in your life turning-point that was a great word
with you before they dried up altogether always having turning-
points and never but the one the first and last that time curled up
worm in slime when they lugged you out and wiped you off and
straightened you up ... (Beckett 1986:390)

Here we are beyond turning points and perhaps beyond autobiography. Yet Beckett's play does point towards some of the features of the kind of autobiographical process I am describing. Here a vigilant consciousness, attuned to its own endless transactions with a world it still vestigially inhabits and where it used to come and go, recognises that full remembrance, equated with confident utterance, is a sign of oblivion and that paying real heed to the voices of selfhood involves dealing with gaps, erasures and contradictions.

That is why it seems worth pursuing the question of forgetting in autobiography. If we do so, we will gain many insights into what is happening in Rousseau, 
Stendhal, Wordsworth or James. We will also understand better what goes on in many of the most interesting contemporary works of autobiography; for example, in such French writers as Georges Perec, Marguerite Duras, Assia Djebar, Jacques Roubaud or Louis-René Des Forêts. If autobiographical practices have moved from the cultural periphery to the centre in recent years, it is partly because a renewed sense of the complexity of the autobiographical process, foregrounding questions of memory and forgetting, has accompanied a wider sense of the importance of memory and forgetting. The role of collective memory (or amnesia) in national identity; the connection between individual acts of recollection, witness, testimony and the historical record; an awareness of the conflict between the duty to remember - marked by remembrance-day ceremonies - and the need to forget; between truth and reconciliation, these are just some of the important themes in our period which not only find a mirror in autobiographical practice but are a source of creative thinking about issues of gender, ethnicity and history in the context of collective and individual identity. When it acknowledges and enacts the work of memory and forgetting, autobiography helps clarify and negotiate complex relationships between private and public, individual and collective, historical and personal, pasts, presents and futures. It can illuminate, at the level of lived experience, conflicts and paradoxes to which remembrance gives rise, such as the asymmetries between remembering and forgetting. We can pretend that we have forgotten something when we have not, and nothing prevents us from pretending to remember when we cannot or could not. Is there not, however, a radical difference in affective and psychic structure between these two cases? Equally, we can commit ourselves to remembering something - as in Québec where every car's number-plate bears the words 'Je me souviens' - but can we commit ourselves to forgetting something?

In the first case, if we try, we are likely to succeed - although the horror of involuntary forgetting, progressively losing someone's image for example, is a central theme in works such as Marguerite Duras's haunting Hiroshima mon amour (1994) and Georges Perec's W, or the Childhood Memory (2010).

However, in the second case - of striving to forget - there seems to be a contradiction between effort and achievement: Trying to forget, like trying to get to sleep, is a recipe for the opposite. It is known that in $403 \mathrm{BC}$ the Greek polis after a bloody civil war decreed that the war should be erased from memory: Anyone mentioning it was summarily executed. One suspects, however, that remembering what they were supposed to forget kept the events fully alive in people's memories, and, more generally, when two or more people agree to forget, it is important that they do not forget what they have agreed upon.

If forgetting is a crucial component in autobiography, it is in a context where questions of pardon (pardoning oneself and others), amnesty, deliverance - and more generally the uses of the past in preparing or making way for the future - are often to the fore. Such questions have been seen to have important reverberations, as recent work by Paul Ricoeur, Jacques Derrida, Harald Weinrich and others amply demonstrates.

It is with the autobiographical process itself that I want to end, a process where, as I tried to show in different ways, remembering and forgetting are inseparable. So I shall conclude with some lines by Emily Dickinson which, when translated by Pierre Leyris in 1948, inspired a French poet, Jules Supervielle, to write an extraordinary sequence of poems about the creative role of forgetting in the memory process, entitled Oublieuse mémoire - 'A memory that is a forgetting' (Supervielle 1948). Supervielle's poems prompted in turn a fine commentary by Maurice Blanchot where he wrote (Blanchot 1969): 'Forgetting is memory's vigilance, the powerful guardian that preserves the hidden side of things, thanks to which human beings may rest in the hidden side of themselves' (p. 460).

Emily Dickinson's (1976:207-208) lines, 'Knows how to forget!', which I have abbreviated a little, are about the desirability - and difficulty - of forgetting, a difficulty conveyed by imagining a treatise - a learned book - on the art, or the science, of forgetting:
Knows how to forget!
But could It teach it?
Easiest of Arts, they say
When one learn how
$\cdots$
'How to forget'!
Say - some - Philosopher!
Ah, to be erudite
Enough to know!
Is it in a Book?
So, I could buy it
Is it like a Planet?
Telescopes would know -
If it be invention
It must have a Patent
Rabbi of the Wise Book
Don't you know?

\section{Acknowledgements Competing interests}

The author declares that he has no financial or personal relationships which may have inappropriately influenced him in writing this article.

\section{References}

Augustine, 1961, Confessions, transl. R.S. Pine-Coffin, Penguin, London.

Baudelaire, C., 2013, CEuvres complètes, Editions la Bibliothèque Digitale, Paris.

Beckett, S., 1986, The complete dramatic works, Faber, London.

Benjamin, W., 2006, Berlin childhood around 1900, transl. H. Eiland, Belknap Press of Harvard University Press, Cambridge. 
Blanchot, M., 1969, L'Entretien infini, Gallimard, Paris.

Campbell, R., 1952, Poems of Baudelaire: A translation of Les Fleurs du mal, Harvill Press, London.

Dickinson, E., 1976, Complete poems, Faber, London.

Duras, M., 1994, Hiroshima mon amour, transl. R. Seaver, Grove Press, New York. James, H., 1987, The complete notebooks of Henry James, ed. L. Edel \& L.H. Powers, Oxford University Press, Oxford.

Kermode, F., 2010, 'Palaces of memory', Index on Censorship 18 August, viewed 15 June 2015, from http://indexoncensorship.org
Kundera, M., 1999, The book of laughter and forgetting, Harper Perennial, New York. Malcolm, X., 1987, The autobiography of Malcolm X: As told to Alex Haley, Random House, New York.

Perec, G., 2010, W, or the childhood memory, David R. Godine, Boston.

Phillips, A., 1994, On flirtation: Psychoanalytic essays on the uncommitted life, Harvard University Press, Cambridge.

Supervielle, J., 1948, Oublieuse mémoire, Gallimard, Paris.

Woolf, V., 1953, A writer's diary: Being extracts from the diary of Virginia Woolf, ed. L. Woolf, Harvest, New York. 